\title{
Exploring the Use of Digital Games as a Persuasive Tool in Teaching Islamic Knowledge for Muslim Children
}

\author{
Madihah Sheikh Abdul Aziz ${ }^{1}$, Panadda Auyphorn ${ }^{2}$, Mohd Syarqawy Hamzah ${ }^{3}$ \\ Kulliyah of Information and Communication Technology \\ International Islamic University Malaysia (IIUM), Selangor, Malaysia
}

\begin{abstract}
Various digital games have been developed that focus on providing a sense of enjoyment and excitement for their players in order to be a modern tool for releasing stress or simply for pleasure. In recent years, digital games were also used for teaching and learning. For example, in History subject, games were used for retelling historical stories; at the same time, to preserve the history for the next generation to learn, understand and appreciate. Similarly, Digital games with Islamic values have also been developed to teach Islamic values or knowledge among players, in other words to persuade players to learn or improve their knowledge on Islam. Many designers assumed that games could be used as a persuasive tool to influence players, to learn and understand Islam as a way of life. However, no prior research has been done on the perception of players before and after playing Islamic digital games. To this end, this paper investigates and reports if Islamic Digital Games could persuade gamers to understanding Islam by exploring the use of these games among gamers. A total of 20 school children voluntarily participated in the experiment and the findings are reported in this paper. The study found positive effects on the users' perception toward playing digital games embedded with Islamic values.
\end{abstract}

Keywords-Digital games; persuasive tool; Islamic knowledge; Islamic values

\section{INTRODUCTION}

Games vary from computer-delivered interventions by aspiring to be highly enjoyable, attention-captivating and intrinsically motivating $[1,2]$. Serious games differ from mere entertainment games in their aim to educate or promote behaviour change. Similarly, serious digital games with religious elements in this context, religion of Islam, are a type of computer-delivered intervention considered to be both educational and fun. Elaborating further, the main aim of these games is to educate or promote behaviour change towards knowing, understanding, and practicing Islam as a way of life. In the context of promoting Islam, this may be achieved via the provision of Islamic-related information, teaching and learning Qur'an (the Islamic sacred book for the Muslims), modeling of positive behaviours, the creation of opportunities to practice Islamic lifestyle; by reading du'a (say a prayer) before and after sleeping; eating or learning. Sitzmann [3] and Wouters, Van Nimwegen, Van Oostendorp, \& Van Der Spek [4] highlighted that, serious games may furthermore create sustained effects by being intrinsically motivating to play longer and repeatedly. For example, in the context of this research, religious digital games with Islamic elements like mobile Qur'an, should be played longer in the effort to memorize Quranic verses in the Qur'an.

\section{RELATED WORK}

Serious games are formulated to derive their learning effects from at least three sources: 1) by creating immersion or engagement, a state in which the player becomes absorbed in the play without disbelief, while creating personally relevant experiences and deep affection for the characters; 2) by establishing flow, a state of high concentration in which the player experiences a balance between skills and challenge; and 3 ) by meeting the individuals' needs for mastery, autonomy, connectedness, arousal, diversion, fantasy, or challenge [5-9].

According to the literature, there are a few studies uses serious digital games with religious elements to inculcate Islamic knowledge among children. For instance, Lotfi, Amine, Fatiha, and Mohammed [10] developed a serious game for teaching ablution and praying correctly. They have tested the game with children and adult students. The results suggest that the players were satisfied with the game and express their intentions to practice in the daily life. In another similar research, Paracha, Jehanzeb, \& Yoshie [11] used a serious game to teach Islamic values in school children. During the experiment, they were asked to play the game, and upon completion, they were asked with a series of interview questions. The results showed that the game increased moral values, empathy and awareness on intimidation that children have to overcome.

In relation to persuasion, Fogg [12] coined a model named Fogg Behaviour Model that focuses on behaviour change and it has been used as a tool for analyzing behaviour change. The Fogg model proposed three fundamental elements which are motivation, ability and trigger (behaviour trigger) and stated that to contribute a target behaviour, "a person must have sufficient motivation, sufficient ability, and an effective trigger. All three factors must be present at the same instant for the behaviour to occur."

For example, Ponnada, Ketan, \& Yammiyavar [13] developed a digital game to persuade players based on the three elements of Fogg in order to change the diffidence of players to become more sociable. The game motivates players by offering rewards and enhances a player's ability by asking new friends to help them in fighting off bullies and the game's 
signals on the interface act when acted upon i.e. triggers behavioural change.

This idea of using game as a persuasive tool was also explained by King, Delfabbro, \& Griffiths [14] revealing that; presentation (i.e., graphic or sound in a game), social (i.e., share button), manipulation and control (i.e., loading screen or control keys), narrative (i.e., story in a game), reward and punishment features (i.e., bonus point or star) are often important in developing a serious digital game. In addition, narrative features can cause long-term player or addiction, while reward and punishment features evoked a sense of enjoyment.

Recent research shows that serious games with religious elements can be used to instill Islamic knowledge, practices and values for players, for example in changing and shaping people's mindset towards a certain Islamic topic. They added that the games can instill the positive attitude on players such as compassion, forgiveness, responsibility and sociability [11].

Shelton \& Scoresby [15] highlighted that the important features that could directly affect and effect high school students include narrative feature and instructional goals. Elaborating further, a narrative feature (or game story) embedded lessons and simulated situations to players. Meanwhile, instructional goals were designed in such a way to encourage players to be able to comprehend lessons in a game. Lotfi et al., [10] also emphasized on adding narrative feature(s) to gain attention of the players and develop main character(s) to facilitate learning process such as ablution and praying. These features played a significant role in increasing awareness and perception for players. Another example, Paracha et al., [11] use story (narrative feature) in a game such as a bully situation in order to simulate situations and provide solutions. According to the results, the players gained encouragement, empathy and Islamic moral after playing the game [11]. Shelton et al. also showed that the reward and punishment features like getting extra point or life can enhance the challenge and brings out the fun in games. However, focusing on too much fun may not allow the game players to achieve game's objectives.

Players can learn a lesson when interacting with the game elements such as goals and role-playing. For instant, Muslim Kid in Evil Land game simulates the pre-Islamic Persia and requires a player to act as a practicing Muslim kid. The player is challenged to achieve the game's goals which are calling and guiding people to Islam by fighting magician's evil animals and the dark forces [16]. Therefore, it is safe to conclude that the narrative feature, reward and punishment, goals and role-play among others are significant factors for developing effective digital games with religious elements.

Although various research have been carried out relating to religious elements in games, no prior research explored on the perception of players before and after playing these games. This paper seeks to evaluate games with Islamic elements as a persuasive tool to teach Islamic Knowledge among children with Islam religion, also known as the Muslim. The next section explains the method used in this study.

\section{METHOD}

Twenty primary school students (11 female, ranging from 6 to 12 years of age) voluntarily participated in the evaluation. Out of 20, ten participants were from English-based learning school in Gombak, Malaysia and another ten were from Thaibased learning school in Bangkok, Thailand. Participants were asked to play with the games in individual sessions taking between 15-30 minutes each. Instructions to participants, the informed consent form, and a demographic information form were provided and given to them. All sessions were audio recorded with permission and transcribed verbatim.

For this study, three games were selected from the AlQur'an category [17]. This category was selected, at least for a start, considering that the Holy Qur'an as the root of Islamic knowledge and as the main reference for all Muslim in the world. The three games selected were listed in Table I.

Upon arrival in the test venue, participants were welcomed and briefed about the experiment. Next, they were asked to play each game, they were asked to verbalize their thoughts as they went. At the end of each game, participants were asked to fill out a survey questions CEGE Questionnaire (CEGEQ). The CEGEQ was adopted evaluating the ten core elements of gaming experiences which cover sound, graphics, general environment, rules, story, enjoyment, goal, time, and rewards [18]. CEGEQ was a paper-based with 7-point Likert scale questions with (1) being strongly disagree and (7) being strongly agree as depicted in Table II. It consisted of two parts: the first part generally asked about the background details of each participant, and the second asked about their experiences toward playing digital games with Islamic values.

TABLE I. LIST OF GAMES SELECTED IN THIS StUdy

Ali and Sumaya let's Read


TABLE II. CEGE QUESTIONNAIRE (CEGEQ) GIVEN TO PARTICIPANTS AFTER EACH GAME

\begin{tabular}{|l|l|}
\hline Questionnaire Questions & Elements \\
\hline I enjoyed playing the games & Enjoyment \\
\hline I like the games & Enjoyment \\
\hline I would play this game again & Enjoyment \\
\hline I like to spend a lot of time playing this game & Time \\
\hline I understood the rules of the games & Rules \\
\hline The game was fair & Rules \\
\hline The game was interesting & Enjoyment \\
\hline The game was difficult & Rules \\
\hline I knew what to do to win the game & Goals \\
\hline The graphics were proper for the game & Graphic \\
\hline $\begin{array}{l}\text { The graphics and sound effects of the game were } \\
\text { proper }\end{array}$ & General \\
\hline The sound effects of the game were appropriate & Environment \\
\hline The sound of the game affected the way I was playing & Sound \\
\hline The story of the game was interesting & Story \\
\hline The game kept motivating me to keep playing & Rewards \\
\hline
\end{tabular}

TABLE III. INTERVIEW QUESTIONS

\begin{tabular}{|l|l|}
\hline No. & Interview Questions \\
\hline 1 & Which game do you think is the best? \\
\hline 2 & Why do you like the game? \\
\hline 3 & What did you learn from the game? \\
\hline 4 & Can you apply the Islamic knowledge learned in your life? \\
\hline 5 & Would you like to play Islamic digital games in the future? \\
\hline
\end{tabular}

A semi-structured interview questions were also used after they completed the survey to further investigate and identify the perception of players towards playing these digital games. Table III summarized the interview questions. All sessions were audio recorded with permission and transcribed verbatim.

\section{RESULTS AND DISCUSSION}

\section{A. Pilot Study}

It is important to note here that prior to the actual test; a pilot study was conducted first with 2 primary school students aged 6 and 7 years old following the exact procedure as mentioned earlier. Based on the study, we found that some corrections need to be made on the questions used for example, some vocabularies used were difficult for the children to understand, and therefore, the questions were then corrected with simpler wordings.

\section{B. Actual Study}

1) Survey data: In relation to their demographic background, the participants were separated based on English literacy into Thai and International groups. For an international group, it consisted of various nationalities which are 2 Malaysian, 3 Nigerian, 2 Somalian, 1 Syrian, 1 Indonesian and 1 Sri Lankan. The average age for participants from Thailand and other International participants were 7 and 8 years old, respectively.

In the survey, when asked if they have played with any Islamic Digital Games before, fifteen out of $20(75 \%)$ said

This research is fully sponsored by International Islamic University Malaysia through Research Initiative Grant Schemes (RIGS15-072-0072) never. Others mentioned only rarely for both groups of participants; Thai and others. The genre that they like the most was Action game with $40 \%$ (Thai participants), and 50\% (other participants) said they have no preferences. Based on the demographic of both groups, the Thai group had problem to understand the games due to language barrier and lack of Islamic knowledge related to the content of the games (AlQuran) as compared to the other group of participants with different nationalities.

Based on Table IV, the international participants enjoyed and would like to keep playing compared to Thai participants as shown in the mean values of users' perception. For user's abilities, the mean values of international participants are ranged between 2.1 to 7.0 , higher than the Thai participants. However, in terms of the game as being interactive, the mean values of both participant groups were similar at over 6.1. For $\mathrm{P}$-value, the significant is 0.01 level for difficult content and at $\mathrm{p}<0.05$ level on graphic and sound relation for both groups i.e. it is highly significant.

In Table $\mathrm{V}$, the mean values of Users' perception are ranged between 5.6 and 6.8. For Users' abilities, the Noor Quest game is more difficult for Thai respondents (mean = 3.3) compared to International respondents $($ mean $=1.8$ ). However, for the game interaction, the mean values of both groups are quite similar with the value of over 6.0.

Table VI shows that both groups have similar mean value for users' perceptions; although, the game was more difficult for the Thai participants. Furthermore, the game interaction section was similar in mean values for both groups which surpassed 5.9. For P-value, the significant was at 0.02 level based on how difficult the content of the game was for both groups.

TABLE IV. SURVEY RESUlts For THE ALI AND SuMAYA'S GAME

\begin{tabular}{|l|l|l|l|}
\hline \multirow{2}{*}{ Construct } & \multicolumn{2}{|l|}{ Mean } & P value \\
\cline { 2 - 4 } \multicolumn{2}{|l|}{ Thai $(\boldsymbol{n}=\mathbf{1 0})$} & $\begin{array}{l}\text { International } \\
(\text { n=10) }\end{array}$ & \\
\hline Users' perception & 6.9 & \\
\hline Enjoyment & 6.3 & 6.5 & .103 \\
\hline Favorite & 6.6 & 6.7 & .795 \\
\hline Continuance & 6.2 & 5.5 & .299 \\
\hline Time & 5.9 & & .649 \\
\hline Users'abilities & 5.6 & 7.0 & \\
\hline Understanding & 6.2 & 6.5 & .077 \\
\hline Fairness & 6.4 & 6.8 & .536 \\
\hline Interesting & $5.3^{*}$ & $2.1 *$ & .363 \\
\hline Difficult content & 5.2 & 6.7 & .001 \\
\hline Accomplishment & & & .084 \\
\hline Interactive game & 6.8 & 6.1 & \\
\hline Graphic & $7.0^{* *}$ & $6.2^{* *}$ & .080 \\
\hline $\begin{array}{l}\text { graphic and sound } \\
\text { relation }\end{array}$ & 6.8 & 6.7 & .037 \\
\hline Sound suitability & 6.8 & 6.5 & .696 \\
\hline Sound effect & 6.3 & 6.8 & .177 \\
\hline Story & 6.3 & 6.4 & .216 \\
\hline Motivation & & .856 \\
\hline \multicolumn{2}{|l|}{} & \\
\hline
\end{tabular}


TABLE V. SURVEY RESULTS FOR THE NOOR QUEST'S GAME

\begin{tabular}{|c|c|c|c|}
\hline \multirow[b]{2}{*}{ Construct } & \multicolumn{2}{|l|}{ Mean } & \multirow[t]{2}{*}{ P value } \\
\hline & Thai $(n=10)$ & $\begin{array}{l}\text { International } \\
(n=10)\end{array}$ & \\
\hline \multicolumn{3}{|l|}{ Users'perceptions } & \\
\hline Enjoyment & 6.7 & 6.8 & .736 \\
\hline Favorite & 6.4 & 6.8 & .324 \\
\hline Continuance & 6.3 & 6.4 & .836 \\
\hline Time & 6.6 & 5.6 & .216 \\
\hline \multicolumn{3}{|l|}{ Users'abilities } & \\
\hline Understanding & 5.9 & 6.9 & .156 \\
\hline Fairness & 6.5 & 6.8 & .331 \\
\hline Interesting & 6.3 & 6.4 & .886 \\
\hline Difficult content & 3.3 & 1.8 & .142 \\
\hline Accomplishment & 6.9 & 6.8 & .662 \\
\hline \multicolumn{3}{|l|}{ Interactive game } & \\
\hline Graphic & 6.8 & 6.5 & .382 \\
\hline graphic and sound relation & 6.8 & 6.1 & .146 \\
\hline Sound suitability & 6.8 & 6.6 & .556 \\
\hline Sound effect & 6.8 & 6.7 & .696 \\
\hline Story & 6.6 & 7.0 & .168 \\
\hline motivation & 6.6 & 6.7 & .749 \\
\hline
\end{tabular}

TABLE VI. SURVEY RESUlts For THE MABLE LEARNS QUR'AN's GAME

\begin{tabular}{|c|c|c|c|}
\hline \multirow[b]{2}{*}{ Construct } & \multicolumn{2}{|c|}{ Sample $(\mathrm{n}=\mathbf{2 0})$} & \multirow[t]{2}{*}{ P value } \\
\hline & Thai $(n=10)$ & $\begin{array}{l}\text { International } \\
(n=10)\end{array}$ & \\
\hline \multicolumn{3}{|l|}{ Users'perceptions } & \\
\hline Enjoyment & 6.1 & 6.9 & .247 \\
\hline Favorite & 6.0 & 6.3 & .666 \\
\hline Continuance & 6.0 & 6.4 & .600 \\
\hline Time & 5.9 & 5.5 & .675 \\
\hline \multicolumn{3}{|l|}{ Users' abilities } & \\
\hline Understanding & 6.6 & 6.7 & .844 \\
\hline Fairness & 6.7 & 6.2 & .472 \\
\hline Interesting & 6.7 & 6.2 & .274 \\
\hline Difficult content & $5.1^{*}$ & $2 *$ & .002 \\
\hline Accomplishment & 6.1 & 6.2 & .909 \\
\hline \multicolumn{3}{|l|}{ Interactive game } & \\
\hline Graphic & 7.0 & 6.5 & .138 \\
\hline graphic and sound relation & 6.9 & 5.9 & .081 \\
\hline Sound suitability & 7.0 & 6.4 & .111 \\
\hline Sound effect & 6.9 & 6.8 & .660 \\
\hline Story & 6.6 & 6.7 & .714 \\
\hline Motivation & 6.6 & 6.5 & .845 \\
\hline
\end{tabular}

Tables IV, V and VI show that both groups enjoyed playing the three games. Moreover, the three games kept motivating the students by providing efficient interactive game elements such as graphic, sound and story.

In relation to the games as a persuasive tool, the targeted behaviour of the three games as suggested by Fogg Behavioural Model (Fogg, 2009) is to persuade players to complete learning the Qur'anic verses, and answer the quiz that follows in order to unlock and proceed to the next level. The three games substantially motivated the respondents by integrating some interesting elements such as animation, graphic and rewards to motivate players. Those elements may drive pressure to the players and can simultaneously boost up the hope in gaining virtues of learning and reading Al-Qur'an.
In terms of ability, the Ali and Sumaya as well as Mable learn Qur'an games require the players to answer the Qur'anic questions correctly and collect rewards for passing to the next level. The Noor Quest game requests players to find missing Arabic letters by dragging the rocket to catch them in order to unlock the basic Surah. So, the three games are quite simple for the players to achieve the target. However, the games do not considerably focus on using either notification or sound to persuade their players to achieve all the Qur'anic lessons and quizzes. The games should motivate players by using Qur'anic verses or hadeeths (saying of the prophet) regarding the virtues of reading Al-Qur'an such as "The best of you are those who learn the Qur'an and teach it to others." (Al-Bukhari) to remind them in learning as a daily task.

Hence, it can be summarized that the three games provide high motivation but moderate trigger to persuade player to achieve the game's targets while players' ability is high when playing.

\section{Opinion Data}

The results suggest that all three games have a positive influence on the perception of the participants because of the contents and graphical user interface provided. All students from both groups were interested to play with the Islamic games again and request more time for playing. Moreover, some students asked for the name of the games for them to download, and for future use later.

When asked about their most favorite game, nearly half preferred Ali and Sumaya which consisted of Islamic lessons and animation. The participants commented that the game was fun and challenging. Moreover, they liked the animation, the interface as well as Islamic knowledge embedded in the game. Upon completion of the game, they were able to read the surah correctly, as they have learnt how to read Al-Qur'an with the right Islamic manner, rules of Tajweed and pronunciation. For example, participants said, "I will use the game as an alternative way to learn Qur'an" and "the game encouraged me to be a Qur'an lover and I can read the Qur'an correctly". For the Thai participants, many said that for them the game is the basic knowledge for reciting Qur'anic verses correctly and encourages love and appreciation during the recitation.

In addition, $30 \%$ of the participants prefer Noor Quest as the best game due to the narrative element, graphic, engagement and physical movement in the game. The participants expressed that memorizing the Arabic alphabet and the basic Surah for kids can be easy, if they keep playing the game. The participants indicated that the Islamic knowledge in the game can be of benefit to them in the real life because remembering the Arabic letters is the first step to become closer to memorizing and knowing Al-Qur'an. For instant, "the game help me to memorize the Arabic letters and basic Surah", a participant said. Likewise, all thirty percent would like to play the game and other Islamic games in the nearest future.

Similarly, all participants also like the Mable learn Qur'an because of the knowledge, humor and graphic elements. The participants enjoyed playing with the learning rules of Tajweed just to complete the required goal and collect the 
rewards. At that point, players can use the rewards to buy items for decorating their characters. Many participants said that they know Arabic vowel and pronunciation of the Arabic letters that help in reciting the Qur'an correctly through this game. For example, "I can apply the knowledge about Quran in my life", a participant said. Moreover, they expressed that the game can be used as a tool for understanding and memorizing the Qur'an easily and they would like to play the Islamic game again.

\section{CONCLUSION}

The overall results show that the Islamic digital games may have positive effects on the users' perception toward playing Islamic games. Majority of the participants were interested in playing the games and have the intention to play more. The chosen Islamic digital games have discovered the participants' perceptions toward playing Islamic games and persuade them in terms of reading Al-Qur'an. Also, the research findings suggest that the content, rules, graphic, story and sound can be the major elements to be considered for increasing the attractiveness and enjoyment of the game from the Islamic perspectives. Using English as the main language is not a barrier for enjoyment but, can be a barrier in gaining knowledge and values in games. There should be an option for players to switch the language.

The findings of this research may benefit the game designers to venture more into the development of educationbased games embedded with Islamic knowledge, principles or values for the gamers to learn, understand and apply in their daily life. In addition, a game-based learning that teaches Islamic principles or knowledge can be a great tool particularly for the non-Muslim or the new-Muslim to get to know Islam. This conclusion supports our findings, in our recent paper, on the benefits of digital games from the Muslims scholars' perspectives, as reported and discussed in [19].

\section{FUTURE WORK}

The study only focused on the three games for children from Al-Qur'an genre on mobile platforms. Hence, it is suggested that the future research to include games in different Islamic genres to explore further on the effect if these games as well as to ascertain the common and unique design elements to improve Islamic digital games.

The sample size covered 20 participants from different countries which cannot represent the perception of entire gamers toward playing the Islamic digital games. Conducting more research with greater number of participants would yield more insight.

\section{ACKNOWLEDGMENT}

The authors would like to thank the International Islamic University of Malaysia for funding this research under the Research Initiatives Grant Scheme RIGS15-072-0072.

\section{REFERENCES}

[1] Graesser A, Chipman P, Leeming F, Biedenbach S. Deep Learning and Emotion in Serious Games. In: Ritterfeld U, Cody M, Vorderer P, editors. Serious Games, Mechanisms and Effects. New York and London, Routledge: 2009.

[2] Prensky, M. Don't bother me, Mom, I'm learning! How computer and video games are preparing your kids for 21st century success and how you can help! 2009, St. Paul, MN: Paragon house.

[3] Sitzmann, T. A meta-analytic examination of the instructional effectiveness of computer-based simulation games. Personnel psychology 64.2, 2011, pp. 489-528.

[4] Wouters, P., Van Nimwegen, C., Van Oostendorp, H., \& Van Der Spek, E. D. A meta-analysis of the cognitive and motivational effects of serious games. Journal of educational psychology 105, no. 2, 2013, 249.

[5] Annetta LA. The I's Have It: A Framework for Serious Educational Game Design. Review of General Psychology. 2010, 14(2), pp. 105-112

[6] Boyle EA, Connolly TM, Hainey T, Boyle JM. Engagement in Digital Entertainment Games: A Systematic Review. Computers in Human Behaviour. 2012, 28, pp. 771-780.

[7] Connolly TM, Boyle E, Macarthur E, Hainey T, Boyle JM. A Systematic Literature Review of Empirical Evidence on Computer Games and Serious Games. Computers \& Education. 2012, 59, pp. 661686.

[8] Kapp KM. The Gamification of Learning and Instruction: game-based methods and strategies for training and education. San Francisco, CA: John Wiley \& Sons; 2012.

[9] Lu, Amy Shirong, Tom Baranowski, Debbe Thompson, and Richard Buday. "Story immersion of videogames for youth health promotion: a review of literature." Games For Health: Research, Development, and Clinical Applications 1, no. 3, 2012, pp. 199-204.

[10] Lotfi, E., Amine, B., Fatiha, E., \& Mohammed, B. Learning to pray, islamic children's game. In International Conference on Multimedia Computing and Systems (ICMCS),2014, pp. 622-627. IEEE.

[11] Paracha, S., Jehanzeb, S., \& Yoshie, O. A serious game for inculcating islamic values in children. In Taibah University International Conference on Advances in Information Technology for the Holy Quran and Its Sciences, 2013, pp. 172-177. IEEE.

[12] Fogg, B. A behaviour model for persuasive design. Proceedings of the 4th International Conference on Persuasive Technology, 2009, 1.

[13] Ponnada, A., Ketan, K. V, \& Yammiyavar, P. A Persuasive game for social development of children in Indian cultural context. 4th International Conference on Intelligent Human Computer Interaction (IHCI), 2012, pp. 1-6.

[14] King, D., Delfabbro, P., \& Griffiths, M. Video game structural characteristics: A new psychological taxonomy. International journal of mental health and addiction, 2010, 8(1), pp. 90-106.

[15] Shelton, B. E., \& Scoresby, J. Aligning game activity with educational goals: Following a constrained design approach to instructional computer games. Educational Technology Research and Development, 59(1), 2011, pp. 113-138.

[16] Tobergte, D. R., \& Curtis, S. Assessment in Game-Based learning. Journal of Chemical Information and Modeling, 2013, Vol. 53.

[17] Aziz, M. S. A., Auyphorn, P., Hamzah, M. S., \& Othman, R. Types of Digital Games with Islamic Values. Journal of Computational and Theoretical Nanoscience, 16(3), 2019, pp. 1100-1103.

[18] Calvillo Gamez, E. H. On the core elements of the experience of playing video games. 2009. UCL (University College London).

[19] Aziz, M. S. A., Hamzah, M. S., \& Othman, R. The Benefit of Digital Games from the Islamic Perspectives: Views from the Muslim Scholars. Journal of Computational and Theoretical Nanoscience, 16(3), 2019, pp. 1104-1107. 